NBER WORKING PAPER SERIES

\title{
DO DEMOCRACIES HAVE DIFFERENT \\ PUBLIC POLICIES THAN NONDEMOCRACIES?
}

\author{
Casey B. Mulligan \\ Ricard Gil \\ Xavier Sala-i-Martin \\ Working Paper 10040 \\ http://www.nber.org/papers/w10040
NATIONAL BUREAU OF ECONOMIC RESEARCH 1050 Massachusetts Avenue
Cambridge, MA 02138
October 2003

The views expressed herein are those of the authors and not necessarily those of the National Bureau of Economic Research.

(C2003 by Casey B. Mulligan, Ricard Gil, and Xavier Sala-i-Martin. All rights reserved. Short sections of text, not to exceed two paragraphs, may be quoted without explicit permission provided that full credit, including $(\mathrm{C}$ notice, is given to the source. 
Do Democracies Have Different Public Policies than Nondemocracies?

Casey B. Mulligan, Xavier Sala-i-Martin, and Ricard Gil

NBER Working Paper No. 10040

October 2003

JEL No. H11, H61, D72

\section{$\underline{\text { ABSTRACT }}$}

Estimates of democracy's effect on the public sector are obtained from comparisons of 142 countries over the years 1960-90. Based on three tenets of voting theory - that voting mutes policy preference intensity, political power is equally distributed in democracies, and the form of voting processes is important - we expect democracy to affect policies that redistribute, or economically favor the political leadership, or enhance efficiency. We do not find such differences. Instead democracies are less likely to use policies that limit competition for public office. Alternative modeling approaches emphasize the degree of competition, and deemphasize the form or even existence of voting processes.

Casey B. Mulligan

Department of Economics

University of Chicago

1126 East 59th Street, \#506

Chicago, IL 60637

and NBER

c-mulligan@uchicago.edu

Xavier Sala-i-Martin

Department of Economics

Columbia University

420 West 118th Street, 1005

New York, NY 10027

and NBER

xs23@columbia.edu

Ricard Gil

Department of Economics

University of Chicago

1126 East 59th Street

Chicago, IL 60637

rgil@uchicago.edu 
How does the source of political leadership affect public policy? Is the public sector run differently when its leaders are elected "fairly"? How, exactly? These questions are important. Nondemocracies are prevalent around the world. The POLITY IV (2000) project provides a widely used dataset on the authority characteristics of modern polities over the last two centuries. According to its estimates, nondemocratic regimes ruled the majority of countries, and the majority of the world's population, until 1991. Even since 1991, more than 40 percent of countries and people were ruled by nondemocratic regimes. Political economy theory devoted to the modeling of democratic institutions might therefore miss much of the world's public sector activity.

A comparison of democracies and nondemocracies may also enhance the understanding of democratic institutions by providing an empirical test of some of the implications of formal voting models. At first glance, it may appear that formal voting models have nothing to say about democratic-nondemocratic policy gaps because they often make no explicit reference to dictators. But there are formal voting theories mentioning authoritarian regimes, some of which we note below. More important, the existing formal voting literature is already based on three tenets of democratic decision-making that would distinguish it from many conceivable models of nondemocracy, and hence imply democratic-nondemocratic policy gaps. First, many formal models have a voting process that mutes the expression of intense policy preferences which leads (in the models) to inefficient policy outcomes. For example, in a democracy the middle-aged and old could benefit themselves by forcing the young to participate in an unfunded Social 
Security program even if the aggregate costs to the young far exceeded the benefits to the old and middle-aged.

A second basic tenet of many formal voting theories is that the distribution of political power is more equal than, say, the distribution of income or wealth, because public decisions are made (directly or indirectly) by voting. This is an important reason why Meltzer and Richard's (1981) model confirms de Tocqueville's (1835) fear that democracies would excessively redistribute from rich to poor. Acemoglu and Robinson (2003, p. 2) are explicit about this theoretical result: "[D]emocratic regimes generally choose policies that are more favorable to the poor than nondemocratic regimes." By the same logic, the skewness of the distribution of taxable income can be an important determinant of income redistribution in democracies, because it measures the amount that the middle class can gain by forming a voting coalition with the poor (see also Alesina and Rodrik, 1994; Tabellini, 1992). Hence, there should be an interaction between democracy, income inequality, and other variables determining public policy (see also Boix 2003, p. 176).

Olson, McGuire, and Niskanen have a series of theoretical papers based on the second tenet. ${ }^{1}$ One result is that broad-based taxes will be levied at lower rates in democracies, where each taxpayer has a say in public decisions, than in nondemocracies where (in theory) the political leadership and its sponsors are a small minority of taxpayers. Hence in their models nondemocracies tax more, even while they are spending less on the poor.

A third tenet of formal voting theory is that the "form of the game is important," and not just a reaction to efficiency considerations. As explained by Myerson (1995), an important goal of game theoretic models of public choice is to predict how different political institutions would result in different policies. For example, it should matter (for policy) whether a nation is divided

\footnotetext{
${ }^{1}$ Olson (1993), Olson and McGuire (1996), and Niskanen (1997). Tullock (2002)
} 
in to electoral districts, with each district electing one policy-making representative, or whether the whole nation votes on the same list of policy-makers with the top vote-getters making policy. From the perspective of game theory, politics could hardly be more different in democracies versus nondemocracies. If policy instrument $p$ were found (empirically) to be the same function of economic and demographic variables in democracies and nondemocracies, then it seems that the best positive theory of $p$ would not rely on any of these three tenets, except in the unlikely case that the best model of authoritarian regimes also adhered to the three tenets. In other words, the three tenets imply that a measure of democracy, perhaps interacted with other variables, should help predict public policy, holding constant economic and demographic variables.

At the other extreme from formal voting theory are positive theories of public policy such as Barro (1979) or Wittman (1989), where efficiency is the main determinant of public policy, while political factors - such as the mechanism by which public decisions are made - are presumed to be either unimportant or just reactions to efficiency considerations as various agents use the political sector to facilitate bargaining with each other (as in Weingast and Marshall's 1988 model). Related are the "Chicago Political Economic School" approaches of Stigler (1971), Peltzman (1976, 1980), Becker (1983), and others who admit that public policies may create inefficiencies such as monopoly rights or excessive taxation, but nonetheless deemphasize political institutions as determinants of public policy. ${ }^{2}$ Instead they emphasize economic and demographic variables such as interest group size, group cohesion, urban location, and the technology of tax collection as determinants of public policies via their effects on both the public interest and on the political success of special interests. Conflicts over policy must be mediated

\footnotetext{
${ }^{2}$ Peltzman (1980, p. 221) explains "majority voting considerations...should not be interpreted literally...what is essential here is simply that popular support contributes to the viability of public policies...." Perhaps Stigler's (1970) analysis of the political success of the middle class ("Director's Law") is an exception, but even this article gives as much attention to the tax collection technology as to the voting process.
} 
by any political leader (whether democratic or not), and these are some of the variables that may determine the outcome.

Some studies modify formal voting theory by including log-rolling (e.g., Tullock 1959 and Coleman 1966), endogenous voter turnout (Ledyard 1984), campaign spending (Grossman and Helpman 1996), and other factors in order to relax or deviate from some of the three tenets (and may go so far as to conclude that policies are efficient!). But much formal voting theory still uses the three tenets and, in comparison with the Chicago School, illustrate two very different perspectives on constructing positive theories of the public sector.

Simply put, it is important to know the empirical importance of economic and demographic variables relative to political institution variables as determinants of public policies. Our paper focuses on the institution of democracy - the fair election of key public officials - as one of the potentially important political institution determinants. The first part of our paper therefore compares economic and social policies observed across countries and over the years 1960-90 to obtain an estimate of the effect of democracy on the public sector. A broad range of policies are measured in a way that includes a broad cross-section of countries, and at the same time includes items from all three of the tax, subsidy, and regulatory arenas. We also made sure to include several policy measures, such as programs and tax provisions that might redistribute from rich to poor, education spending, and conscription where previous authors (based on the three tenets) had suggested that differences should arise between democracies and nondemocracies.

Looking across countries and over the years 1960-90, we observe no systematic economic or social policy difference between democracies and (noncommunist) nondemocracies. This is not to say that democracies and nondemocracies are alike in every way; the second part 
of our paper shows that differences are readily found in another policy arena, namely those relating to the process of winning and maintaining public office (torture, execution, censorship, military spending, and regulating religion). By distinguishing economic and social policies from policies that limit political competition, the second part of our paper reflects an influence of a third "barriers to entry" approach originating with Becker (1958), Tullock (1987), Wintrobe (1990), and pursued more recently by Volckart (2000) and Tsui (2002). The barriers to entry approach emphasizes that suppression of political competition is an especially important activity for dictators, solely because it helps them retain their position. We take this argument a step further, arguing that nondemocracy affects public policies with the potential for limiting political competition - like torture, execution, and censorship - and affects the "markup" received by the leader who successfully blocks his competition, but otherwise does not affect economic and social policy choices. ${ }^{3}$ In other words, this approach embeds the Chicago Political Economic School in a model of the industrial organization of the public sector, where under all regimes various groups can express their intensity of preference for economic and social policy, but especially under the nondemocratic regimes are blocked from expressing their preference for who holds public office.

\section{Cross Country Regression Evidence}

In recent years, the country-panel data used in the economics and political science literatures has expanded significantly and improved in quality. There are also multiple political

\footnotetext{
${ }^{3}$ In theory, the markup may come in the form of a bit extra government revenue, some of which may be spent on activities limiting political competition.
} 
science data sets measuring the extent and form of democracy in nearly all the countries of the world and, for any one of those countries, providing distinct democracy measures for each of dozens (if not hundreds) of years. In this section we begin by discussing how we measure democracy and what other economic and variables might also shape what policies are chosen. We then display a cross-country regression estimates of the effect of democracy on "economic and social policies," conditional on some economic and demographic characteristics of countries. Four of the policy variables are amounts of government spending on various programs, while four others are measures of the amount and design of taxation. Six of the eight are arguably important income redistribution instruments.

\section{Measuring Democracy}

To examine how democracy influences policy choices, the starting point is measuring democracy. The POLITY IV (2000) project from the University of Maryland calculates various measures of how a country is governed for 181 countries going back as far as 1800 . Of the 181 , 142 countries existed for more than a few of the years from 1960-90, which is the main timeframe of our analysis. Practically every piece of the land on the earth is represented by one these 142 countries, except for some island nations. The POLITY data are fairly complete, but they are missing during years of occupation, political interruption, or political transition, which might include occupation by foreign powers, a collapse of central political authority, or an executive guided process of institutional planning). Since our study begins with the three tenets of voting theory, it is important that the POLITY index measures the existence and fairness of the voting process, rather than civil liberties, economic freedom or policies that may affect these liberties. 
The POLITY IV data calculates a variety of different measures and indices. We will emphasize their "democracy" index, which takes integer values 0-10. In our empirical work, we divide the index by 10 to put the numbers on a scale from $0-1$. The democracy index includes as one component an indicator of the extent to which government executives are chosen through competitive elections, plus the presence of rules for political participation and the transfer of executive power. We construct a country's averages (using the available years) for the period 1960-90. ${ }^{4}$ Hence, in a regression of policy index $p$ on democracy and other variables, the democracy coefficient might be interpreted as the partial effect on $p$ of going from 30 years complete autocracy (as in Iraq, North Korea and 35 other countries in our sample) to 30 years complete democracy (as in the U.S., U.K. and 20 other countries).

\section{Other Control Variables}

There is no doubt that variables other than democracy are at least part, and maybe all, of the determinants of the various public policies. Therefore, we also control for some of the variables used in the other literature on the determinants of policy. Five control variables are included in all of our specifications: a dummy variable for whether a country is communist; a dummy variable for whether the country has a British legal origin; the percent of the population over age 65; a measure of the total population; and a measure of per capita GDP. We also

${ }^{4}$ We also experimented specifications that use one of two other alternative POLITY indexes. The first alternative is an "autocracy" index that also takes integer values 0-10, although it weights the "democracy" index components differently (and negatively). A second alternative is just the competitive executive elections component (measured $0,1,2,3$ by POLITY). Replacing the democracy index with one of these others yields very similar results. 
experimented with a number of other control variables, with some of the results presented here, including the share of value added from agriculture, ethnolinguistic fractionalization, the Gini coefficient, and various measures related to military activities.

In all specifications, we include a dummy variable for by whether a country is Communist or not for more than a few years during the period from 1960-90, based on the 26 Communist countries listed by Kornai (1992). Centrally planned economies never had fully democratic political institutions, but unless we were sure that central planning were the consequence of nondemocracy rather than the reverse, it is important to try to separate nondemocracy from central planning. In addition, centrally planned economies are subject to especially severe measurement problems; for example, how large were government purchases or government transfers in the U.S.S.R.? Using the communist dummy variable helps us prevent confounding answers to the relatively easy question "Is the public sector different in a centrally planned economy?" - of course it is (Pryor, 1968; Kornai, 1992) - with the harder question "How does democracy affect the public sector?" Interestingly, as compared with other nondemocracies, communist countries were significantly different in only seven of our 15 policy measures. ${ }^{5}$

Countries with "British" legal systems - namely those relying more on judges, broad legal principles, and oral arguments rather than explicit legal codes - are distinguished from countries with civil law systems (of various types) as measured by World Bank's Global Development Network Growth Database. See Glaeser and Shleifer (2002) for more

\footnotetext{
${ }^{5}$ We also experimented with a "Soviet bloc" dummy, rather than a "communist" dummy, with no substantial effect on the estimated coefficients.
} 
interpretation of this variable; although for our purposes it is not important whether this variable be interpreted as an effect of legal system, or as a proxy for a variety of things British.

Public pensions are a big component of government spending, so it may be important to know how many people are old. For this purpose we use the share of population who is 65 years old or older. The public sector may exhibit economies of scale; for example, Mulligan and Shleifer (2003) suggest that these are quite important for regulatory policy, so we also measure total population. Our population measures come from the ILO (1996) and are available only at ten year intervals. We construct each country's averages for the periods 1960-90, 1960-75 and 1976-90.

The standard of living in a country may influence the level of government services provided. The Penn World Tables (PWT) now report a broad cross-country panel of comparable indicators of standards of living, including real GDP per capita, which we utilize for the years 1960-89. Eleven of the 141 countries are not in the PWT. Eight of these eleven countries are communist; the other three are Equatorial Guinea, Lebanon, and Libya.

We use World Bank variables measuring the fraction of national value added from agriculture, averaged for the years 1960-90, in part because these variables proxy for the level of development, but also because they indicate the fraction of the population that may have been covered by, or have ready access to, various public programs (note that many countries, including the United States, do not or have not covered agricultural workers in some of their programs). Although not reported here, we have also used World Bank measures of the fraction of population in urban areas, and fraction of the labor in agriculture.

Finally, we include in some cases a measure of military situations as a control variable. For example, we include years in which the country was at war (from Jones, Bremer, and Singer 
1996) in regressions about military spending and conscription. Young men are important inputs into military activities, so we also measure the number of males aged 15-24 in each country. Like the information on the share of the population who are elderly, this data comes from the ILO (1996) and is available only at ten year intervals. We construct each country's averages for the periods 1960-90, 1960-75 and 1976-90.

Spending Policy: Government Consumption, Education Spending, and Social Spending

Government consumption, government revenue, education spending and social spending do not significantly impact political entry barriers (more below on how we classify policy instruments on their potential to limit competition for public office), so we consider them first as a group in our comparison of democratic and nondemocratic public sectors. Table 3's columns (1)-(3) are regressions for government consumption, measured as a percentage of GDP. Most countries in our sample are measured to have government consumption between 10 and 30 percent of GDP. The democracy coefficient in column (1) is statistically insignificant, although the magnitude is fairly large. Since we find democracies to spend about 3 percentage points of GDP less on the military (more the military later), and military is a component of government consumption, our point estimate implies that democracies are spending somewhat more on nonmilitary government consumption. However, if we include military spending as an independent variable - column (2) repeats column (1) for the smaller sample required to do this we still fail to find a statistically significant difference between democractic and nondemocratic government consumption. ${ }^{6}$ Perhaps another difference between our government consumption and

\footnotetext{
${ }^{6}$ We also experimented with using (government consumption - military spending) as the dependent variable. The coefficient on democracy remains statistically insignificant. Also, our results do not change substantially is we exclude the four countries that according to Summers and Heston (1991, p. 342) have particularly questionable national accounts.
} 
military spending regressions is that the former is monitored by the Stockholm International Peace Research Institute, which provides an outside and somewhat impartial source of information on military expenditures, whereas the government consumption figures from the Penn World Tables are based in part on national accounts information provided by each government. Large countries, poor countries, and British legal origin countries spend a greater fraction of GDP on government consumption.

According to the Chicago Political Economic School, and the barriers-to-entry qualification of it, education and social spending - for that matter any spending that does not directly benefit the dictator or help him block competition for his office - should not be significantly correlated with democracy. ${ }^{7}$ Education spending (also expressed as a percentage of GDP; from UNESCO) is the dependent variable in columns (4) and (5). The coefficient on democracy is statistically insignificant. The communist coefficient is more than 1 percent of GDP, which may be consistent with Lott' s(1999) finding that totalitarian countries spend more of their GDP on education. ${ }^{8}$ Richer countries, smaller countries, and perhaps also British legal origin countries also spend more on education.

Policy instruments that have the potential to redistribute from rich to poor may provide the toughest test of the hypothesis that "voting is not an important determinant of public policy." Voting models like Meltzer and Richard (1981), Boix (2003), and Acemoglu and Robinson (2003) emphasize the equal distribution of votes as to compared to income and wealth, so that

\footnotetext{
${ }^{7}$ The barriers-to-entry approach has one qualification of this, because political barriers to entry permit the dictator to collect a "markup," which raises the marginal deadweight cost of taxes that can be directed to programs not benefiting the dictator.

${ }^{8}$ Lott's totalitarian variable is from Freedom House, and may be more similar to POLITY's democracy variable than to our Communism variable. He includes a measured of total government size as a regressor; when we do so (not shown in the Table) the democracy coefficient is significantly positive (1.21) and the communist coefficient is -0.19 . Lott does not include British legal original, population, the elderly share, or agriculture as regressors.
} 
democracies should better represent the poor. Among spending programs, those classified as "Social Security" may help the poor. We measure the amount of Social Security spending, as a fraction of GDP and separately for pension and nonpension programs. ${ }^{9}$ The democracy coefficient is negative for pensions and positive for other social spending (specifications (6) and (7), respectively), although neither is statistically significant. The Communist coefficients are significant. Older and less agricultural countries spend more on pensions and other social spending, as shown in the last two columns.

In principle, democracies and nondemocracies may spend the same total amount on education, social security, or some other program, but be very different in how they spend it. Investigating this possibility is beyond the scope of this paper, but elsewhere (Mulligan, Gil, and Sala-i-Martin 2002) we have looked at public pension programs in more detail. Namely, conditional on the age of the population, it is hard to see any correlation between democracy and how pension programs obtain their revenue (using a flat or capped payroll tax, or taxing mainly employers rather than employees), whether benefits are paid subject to a retirement test, or an earnings test. Lott (1999) has a similar finding for public health spending and its composition, but more research is needed to determine whether democracies are special in terms of the detailed composition of their spending on education and other items.

Tax Policy: Corporate Rates, Personal Tax Flatness, Payroll Tax Caps, and Total Revenue We have four measures of tax policy, three of which indicate the degree to which a government taxes the rich. The first is the top rate of corporate income taxation, although

\footnotetext{
${ }^{9}$ As reported by the ILO, nonpension Social Security spending includes "family allowances," "unemployment benefits," "employment injury benefits," and "sickness-maternity benefits."
} 
measured only from 1987-90. Table 2's specifications (1) - (3) show how democracy doesn't predict the corporate tax rate, and the sign of the democracy coefficient depends on whether democracy is measured 1960-90 or 1975-90 (arguably it needs to be measured more recently in the corporate rate equations because that is our only policy variable not dating back to the 1960's or 1970's). None of the demographic and economic variables predict the corporate tax rate, either. $^{10}$

Personal income tax flatness is measured as the ratio of the economy-wide average income tax rate to the top marginal income tax rate (Becker and Mulligan, 2003). Flatter personal income taxes (namely, those that collect a larger fraction of GDP for a given top marginal tax rate) may be associated with less income redistribution. Specifications (4)-(5) show that democratic, old, and fractionalized countries tend to have flatter income taxes. ${ }^{11}$ In other words, specifications (4)-(5) by themselves suggest that democracy and inequality are associated with less redistribution!

The U.S. payroll tax for the Security Programs is collected as $12.4 \%$ of earnings below $\$ 84,000$ annually, and none of the earnings above that. Obviously such a "capped" tax is a less powerful tool for rich-poor redistribution than an uncapped tax such as, say, a 10\% on all earnings. A number of countries have also capped their Social Security tax, and we have coded the fraction of the years 1958, 1975, and 1995 (or subset of these years if data were unavailable for one or two of them) that they did so. Columns (6) and (7) show a small and statistically insignificant (and positive) democracy and fractionalization coefficients. Mulligan, Gil and Sala-

\footnotetext{
${ }^{10}$ All of the cross-country regressions in our paper are ordinary least squares. Although not shown in the tables, we have also estimated every regression as a median regression, with each estimated democracy coefficient essentially the same as its OLS analogue. The only exceptions are the median regression analogues to the corporate tax rate specifications (1)-(3) in Table 2, and our trade openness specification (9) in Table 3. For example, when estimated by median regression, specification (2) has a democracy coefficient of -7.55 (s.e. $=3.27$ ), a communist coefficient of 10.00 (s.e. $=4.49$ ), and an elderly coefficient of $1.00(0.39)$; democracies seem to redistribute less, as measured by the corporate tax rate. See below for more details on trade openness.

${ }^{11}$ The 60 -country sample average and standard deviation of the flatness variables is 0.08 . The U.S. value is 0.18 .
} 
i-Martin (2002, see their paper for detailed data sources) find democracies to be more likely to cap the payroll tax, and their democracy coefficients are statistically significant, using a different index (the Gastil index) to measure democracy. If Table 2 suggests any difference between democracies and nondemocracies, it is that democracies redistribute slightly less than economically and demographically similar nondemocracies.

What about the impact of democracy on total revenue collected by the government? Even if we stick with the three tenets of voting theory, the theoretical effect of democracy on total revenue may not be clear. Some of the models emphasize that democracies collect more revenue because they redistribute more to the poor and middle class. Boix (2003, p. 171) explains: "Under an authoritarian system, where all or a substantial part of the electorate is excluded from the decision-making process, the size of the public sector should remain small.” Olson (1993) also begins his analysis with the highly unequal distribution of political power under authoritarian systems, but stresses that authoritarian governments should act almost as a leviathan - a leviathan taxes up to the point where tax base shrinkage is so severe that no additional revenue can be raised - because the leadership and its sponsors bear very little of the tax burden. Hence Olson's approach suggests that a nondemocracy would have a much larger budget than a democracy, although both approaches agree that nondemocracies would spend little on the poor. For very different reasons, the barriers to entry approach suggests that nondemocracies would raise somewhat more revenue.

In fact we find democracies collecting almost 4 GDP percentage points less in revenue. The barriers to entry approach interprets this 4 percentage points as a markup, part of which would be spent on limiting political competition. Interestingly, nondemocracies are spending almost exactly this amount extra on the military (see below). Our communist coefficient of 9 
percentage points of GDP in the revenue regression is quite large. But as Kornai (1992, p. 138) explains, communist governments have an important revenue source - profits from government enterprises - that is much smaller in other countries. If we remove the Communist dummy from the regression (as in Table 2's last specification) - in effect combining communist countries with other nondemocracies - we see democracies taxing 7 GDP percentage points less.

None of the regressions shown in this paper include interaction terms. But we have interacted democracy with the Gini coefficient, percent agriculture, and percent old. The democracy-agriculture and democracy-Gini interactions never matter (for that matter, the Gini never matters in levels), even when one of them is included by itself to the exclusion of all other interactions terms. When an old-GDP interaction is included - and it should for the same reason that the democracy variable should be in a levels regression together with GDP - the olddemocracy interaction matters only for personal income tax flatness (democracy flattens income taxes, especially when the country is older) and for two of the "barrier to entry" policies studied below.

Policies that Affect Barriers to Entry: Death Penalty, Military Spending, Civil Liberties, State Religion, Conscription and Open Trade

To this point, the main theme is that democracy seems to have little effect on many economic and social policy variables. The cautious reader may wonder whether the lack of correlation between democracy and political policies may be an artifact of poor measures of democracy or policy. While no data in this area is perfect, there are several reasons to believe that measurement error does not drive our results. First, as noted earlier, the quality and quantity of cross-national data has improved and expanded dramatically in recent years. Second, in many 
cases we average each country's economic and political variables over time, with the hope that some measurement errors wash out in the time averages. Third, we identify case study countries (see below) where we are quite confident that a political regime change has occurred, but nonetheless observe little change in economic and social policies. Fourth, we do find significant correlations between democracy and our public policy measures, when public policy is measured as government revenue/GDP or when the public policies measured are among those that arguably limit entry into the competition for political office. The purpose of this section is to display the results for the competition-limiting policy variables.

Our first step is to classify policies according to their potential to limit competition for public office. Tullock's (1987) book is quite useful in this regard, because it gives little attention to the democracy-autocracy policy gap and much attention to autocratic activities related to erecting political entry barriers. Tullock mentions five policy steps that are important for blocking entry: torture (pp. 61, 62, 64, 65), the death penalty (pp. 6, 20, 65, 80), press censorship (p. 154), regulation of religion (p. 108), and maintaining an army. He also mentions conscription and trade barriers, but suggests (pp. $72,123,186$ ) that their impact on political competition is ambiguous. Our other policy measures - education spending, gov. consumption, pension spending, nonpension "social" spending, corporate rate, income tax flatness, and payroll tax caps - are not mention by Tullock and are thereby classified as "economic and social" policies rather than barriers to entry.

Clearly, violent tactics by the government can be expected to cause its potential competitors to pause. Kidnapping, torture, and murder are among these tactics. Ideally we would like measures of the degree to which citizens are deterred from political activity by the potential of the government to use violent tactics. Instead we must settle for three proxies. The 
first proxy comes from a panel data for 142 countries on use of the death penalty. This is not to say that the death penalty serves only the purpose of blocking political entry (it may mainly deter criminal activity), only that nondemocratic governments have more reasons, because of creating barriers to political entry, to put citizens to death. Perhaps also having the death penalty is correlated with use of violent tactics in order to limit competition. The other two proxies - one from the State Department and another from the human rights organization REDRESS - are dummy variables for whether a country has a widespread practice of torture by the police.

The dependent variable in columns (1) and (2) is a dummy variable for widespread torture c. 2002, according to the U.S. State Department and REDRESS, respectively. Our most recent POLITY data are for 1998 and 1999, so our democracy variable here is the average for those two years. Even though "credible" reports of torture have been received from both democracies and nondemocracies around the world, the democracy coefficients are economically significant (and barely statistically significant). Both specifications (1) and (2) include a measure of the number of young men as a proxy for the potential amount of police activity (reports of torture are those committed by the police). Because torture and some of the other barriers to entry behaviors are recorded only when there is a minimum absolute number of internationally recognized incidents, we include log population in all specification to capture the possibility that small countries may have better success at suppressing political competition without international recognition.

We measure the presence of the death penalty by the fraction of years 1976-90 that Amnesty International codes each country as have a "retentionist" policy regarding the death penalty. The sample size is 131 countries, because the Penn World Tables lacks information on per capita GDP over this time in 11 nondemocratic countries. The democracy coefficient of -0.56 
shown in column (3) is economically and statistically significant, and the communist coefficient is much smaller, which means that nondemocracies are much more likely to use the death penalty regardless of whether they are of the communist variety. Interestingly, large and British legal origin countries are more likely to have the death penalty. The coefficient on the GDP variable is small and marginally significant - richer countries use the death penalty more. Results are quite similar when we reduce the sample to the 125 countries with military spending data.

Naturally, we experimented with a number of other specifications not shown in the table. For example, we dropped the per capita GDP variable and ran the regression with a full sample of 142 countries, but the coefficients on the other variables changed little. In specifications that added an explanatory variable for the fraction of population that is Muslim, some observations were lost and the estimated Muslim coefficient is positive, but statistically insignificant, and the other coefficients are very similar to those shown in the table. ${ }^{12}$

Military spending is another policy measure with implications for barriers to entry. The military affects a leader's position in at least three ways. First, a dictator's best competitor may have to take over by force, and the military may have some of the personnel and equipment needed for a coup. Military policy therefore effects this kind of entry, perhaps by keeping the soldiers happy with the regime, or by keeping them occupied with foreign conflicts. Indeed, Elman (1997) uses some of these reasons to explain why nondemocracies might be more prone to international conflict. Second, democratic leaders may have less reason to be concerned with foreign military threats. For example, foreign invaders may be more eager attacking a

\footnotetext{
${ }^{12} \mathrm{We}$ also reran every regression in this paper, adding $\log [($ exports+imports)/GDP] as an independent variable. The democracy coefficient was never affected by the addition, and the coefficient on the added variable was statistically significant in all models except for education spending, nonpension social spending, and total revenue (coefficient was positive coefficient in these cases). Including this variable reduces sample sizes significantly (eliminating mainly nondemocracies), so it was excluded from the regressions shown in the paper.
} 
nondemocratic country because its citizens are less supportive of the regime. Or domestic political competition may leave the country in order to avoid the political repression, and stage an attack from abroad. Third, military personnel may be used for domestic policing purposes. From the perspective of barriers to entry, these factors suggest that democratic nations should have lower military spending.

Specification (5) uses military spending (as a percentage of GDP) as the dependent variable. Its coefficient of -3.44 is large and statistically significant. The communist coefficient is much smaller, which means that nondemocracies spend a couple of percentage points more of their GDP on the military, regardless of whether they are communist. Richer and warring countries spend more of their GDP on the military. Schmitter (1971) and Habibi (1994) also find military spending to be correlated with political regime, and there is a large "democratic peace" literature on democracy and fighting wars. Elman (1997) surveys some of the literature, where findings lean toward some connection between democracy and peaceful foreign policy, at least vis-a-vis other democratic countries.

Press censorship, prohibition of various public gatherings, and other suppression of civil liberties can be used to block entry and/or allow the political leader to gain a public support advantage over the competition. A civil liberties index is the dependent variable in column (6). Freedomhouse.org has an index taking on integer values 1-7 for each country and each year 1973-90, based on indices of human rights, personal autonomy, freedoms of expression, belief, and association (but not on the fairness of the electoral process). In order to form our index, we standardize theirs on a 0-1 scale and average over time for each country. Not surprisingly, column (6) shows how richer and democratic countries have more civil liberties, while communist countries have less. 
An organized religious presence may be able to speak effectively for or against a political leader. Regulating religion can be like regulating the press, so that nondemocracies have added reason to do so. ${ }^{13}$ Column (7), which has as dependent variable the fraction of years 1970,75 , $80,85,90$ that the country had either a state religion or prohibits religious practice shows that richer and nondemocratic countries are more likely to regulate religion, especially the communist countries. ${ }^{14}$

The decision to have a conscripted or volunteer army may have important consequences for political barriers to entry, although the direction of the effect may not be clear. A volunteer army may be happier and more effective at stopping foreign invaders. On the other hand, the regular turnover of soldiers in a conscripted army may hinder the organization and training of military personnel need to stage a successful coup. Ross (1994) predicts conscription in a crosssection of countries, using a democracy index, the size of armed forces, a measure of

${ }^{13}$ Adam Smith (1776, Book V, Part I, "Of the Expence of the Institutions for the Instruction of People of all Ages") explains how politicians join with the clergy, with both parties attempting to stifle their respective competition (we owe this reference to Larry Iannaccone). See Gill (2002, p. 15) for some qualifications of the proposition that political competition promotes religious liberty.

${ }^{14}$ If we change specification (7) to exclude the 9 countries missing information about religious composition of the population, coefficient estimates are hardly changed. If we add fractions of the population Muslim and Catholic, the democracy and communist coefficients (standard errors) are -0.14 (s.e. $=0.16)$ and 0.50 (s.e. $=0.14$ ), respectively. The coefficient on the Muslim and Cathloic fractions are 0.57 (s.e. $=0.13$ ) and 0.32 (s.e. $=0.12$ ), respectively. 
participation in wars, and public spending and independent variables. Mulligan and Shleifer (2003) follow Ross (1994) and add, among other things, British legal origin and log population. Neither finds effects of democracy or public spending on conscription. Mulligan and Shleifer $(2002,2003)$ report a number of cross-country specifications predicting having conscription, including some with corrections for unobserved determinants of the demand for armed forces, and none of them show a statistically significant democracy coefficient. In our findings, the democracy coefficients are almost exactly zero. The other coefficient estimates suggest that smaller countries, common law countries, and countries with smaller armed forces per capital are more likely to have a volunteer rather than a drafted army.

Limiting international trade - if it has the collateral effect of limiting the international flow of political ideas and of military hardware to the political opposition - may help erect barriers to entry, for the same reason press censorship and military spending might. International trade serves many other purposes, and in these other ways may promote popular support. Openness of trade policy is coded 0-1 by Sachs and Warner (1995) for 113 of our 142 countries, for the years 1950-90, based on tariff rates, nontariff trade barriers, the black market exchange rate premium, and whether there was a state monopoly on major exports. ${ }^{15}$ Our "trade openness" policy variable for each country is the fraction of years 1960-90 in which Sachs and Warner coded open. The final specification in Table 3 has this as the dependent variable. The communist coefficient is economically and statistically significant, which perhaps accords with common knowledge that communist regimes limit contact with the outside world. But the reader should also note that communist is part of the definition of Sachs and Warner's variable, and like us they code communist countries using Kornai (1992). The democracy coefficient estimate is positive but statistically insignificant, which means that our data do not permit us to reject the

\footnotetext{
${ }^{15}$ Note that Sachs and Warner automatically code Kornai's 26 communist countries as closed in all years.
} 
hypothesis that noncommunist dictators have the same trade policies as democratic countries. ${ }^{16}$ Interestingly, older and perhaps richer countries have more open trade.

Case Studies

Case studies obviously lack the power of systematic statistical tests, like the regressions presented in the previous section, but they offer some advantages, too. They may sharpen the data by relying more on country-specific data sources. They can help to clarify causal mechanisms; for example, if we think that the death of Francisco Franco in Spain would be the end of dictatorship regardless of when it occurred, and that the year of his death was not affected by Spain's public policies, GDP, or the average age of its population, then the transition from dictatorship to democracy in Spain may offer a sharp test of how such a change affects public policy.

Our overall strategy for selecting countries for closer study is to first look for examples of a dramatic change in political regime (either from democracy to dictatorship or vice versa) and then to observe whether this change is followed by dramatic alterations in the size or the design of various public programs relative to changes occurring elsewhere in the world. Our case study countries are therefore Portugal, Spain, Greece (with Italy as a continuously democratic benchmark), and Chile (with various South American countries as benchmarks). ${ }^{17}$

\section{Spending and Tax Policies}

\footnotetext{
${ }^{16}$ Results from the median regression analogue to specification (9) are somewhat different: the democracy, communist, and elderly coefficients are 0.40 (s.e. $=0.08),-0.17$ (s.e. $=0.06$ ), and 4.80 (s.e. $=0.93$ ), respectively. If POLITY's autocracy index replaces the democracy index, the three OLS coefficients are $-0.24(0.12),-0.31(0.08)$, and 4.61 (s.e. $=1.22$ ), respectively.

${ }^{17}$ See Mulligan, Gil and Sala-i-Martin (2002) for more details on how countries were selected.
} 
Figure 1 displays government consumption of goods and services for the case study countries. Remember that the most recent Portuguese and Greek democratic regimes began in 1975 (Greece also had a democratic regime ending in 1966). In Spain, Dictator Francisco Franco-Bahamonde died in 1975, and a democratic Constitution was adopted in 1978 (arguably, the threat of nondemocracy was still very serious until the early 1980 's). Spain and Greece show slightly more government consumption after 1980. Since continuously democratic Italy (not shown in the Figure) had a very constant ratio of government consumption to GDP during the period 1970-90, this might be interpreted as a small effect of democracy, although Spain's uptrend began several years before the 1978 constitution.

The data for Portugal and Chile show more dramatic correlations with democracy, although in opposite directions. Government consumption in Portugal does seem to rise after the arrival of democracy. In Chile, government consumption was at its peak during its least democratic years (Dictator Pinochet took over in 1973, and Chile made a transition to democracy sometime during the 1980's. Taken together, these four cases do not indicate a systematic effect of democracy on government consumption.

Government revenue over GDP is growing during this period even under democratic regimes, so Figure 2 shows government revenue's percentage of GDP minus the benchmark percentage for Italy for each year. The Italian government collected about 30 percent of GDP in the 1970s, and 35 of GDP in the 1980s. The cross-country estimates suggest that a move to democracy should decrease revenues. However, the Portuguese and Greek series each may suggest about a three percentage point positive effect of democracy on revenue. The Greek series is at its lowest during the early 1970s, during the military regime. Spain's series can be interpreted either way because revenue jumps shortly after Franco dies, although before the 
democratic constitution was adopted in 1978 (is this the effect of eliminating dictatorship?). Revenue/GDP grew slower in Spain than in Italy in the 5-6 years after Spain's constitution was enacted in 1978 (is this the effect of introducing democracy? Or something special about Italy during the period 1979-84?).

Chile's data, which is not shown in this figure, are consistent with the cross-country estimate. According to the IMF, the Chilean revenue share was highest 1975-81 - 32 or 33 percent of GDP - during Pinochet's dictatorship, as compared to 24-29 percent of GDP in the late 1980s. Mulligan, Gil, and Sala-i-Martin (2002) point out how Pinochet added almost 40 percentage points to the employer portion of payroll tax rates between 1973 and 1975.

Mulligan, Gil and Sala-i-Martin (2002) look at time series for public pension spending in Spain, Portugal, Greece, and Chile, as well as the use of earnings tests, retirement tests, delayed retirement credits, payroll tax caps, and splitting of the payroll tax between employer and employee. Transitions to and from democracy were not associated with pension policy changes, except for slower spending growth in nondemocratic Greece, and higher payroll taxation (and pension spending?) in nondemocratic Chile.

The European case studies seem to confirm our cross-country finding that democracies have flatter personal income taxes, although the magnitude of the democracy effect seems smaller in the case studies. During the period 1974-79, many countries in the world were hiking the top personal income tax bracket (eg., Italy's hike from 48 to $72 \%$, France's hike from 48 to $60 \%$ ), the new democracies of Greece, Portugal, Spain were increasing the rate for the top bracket more slowly, or not at all (Greek, Portuguese, and Spanish hikes were 8, 2, and 11 percentage points, respectively) even while they were able to increase personal income tax revenues at rates similar to other countries. 


\section{Policies Potentially Limiting Political Competition}

Our international information on the death penalty dates back to about 1970. Since then, a number of democracies have eliminated the death penalty. A number of other countries like Nicaragua in 1979 and Haiti in 1987 eliminated the death penalty between dictatorships. Perhaps there has been a general trend in both democracies and nondemocracies towards abolishing the death penalty, although we are aware of few nondemocratic countries where the death penalty was eliminated mid-regime (maybe Brazil's abolition in 1979 is an exception). Spain abolished the death penalty as part of the 1978 Constitution establishing its democracy. Portugal did the same two years earlier with the change in regime. As a comparison to these two case, Greece and Chile still keep the death penalty but they restricted its use since 1993 and 2001, respectively. When compared with the rest of the world, these four cases suggest that democracies are less inclined to have the death penalty, or perhaps that democratization happened to be coincident with a worldwide trend towards abolition.

So far as religion regulation is concerned, our data do not indicate many changes from democratic to non-democratic regimes. Portugal, Spain, and Italy had Catholicism as their official religions throughout the period we study (Barrett 1982, 2001). Greece had the Orthodox religion as its official religion. There has been no official religion in Chile, at least since 1970. Therefore our case studies do not suggest that democracy has any influence on the religion regulation, but the reader should recognize that we have not studied communist countries and use a pretty coarse measure of religious regulation.

With one exception noted below, the case studies suggest that democracies spend less on the military. To see this, notice first that, according to SIPRI, Italian military spending is a fairly 
stable percentage of GDP, declining slowly and steadily from about 3 percent in 1960 to about 2 percent in 1990. Portugal quickly decreased its military spending about three GDP percentage points after the end of the military regime. Chile's military spending (at least through 1978) was one or two GDP percentage points higher under Pinochet than prior. Military spending in Greece was a larger fraction of GDP during the most of the military regime than during the relatively democratic early 1960s. So we have three observations suggesting that democracies spend less on the military (SIPRI does not have much information on Spain), but we point out that, recently democratic Greece seems to be spending about 2 GDP percentage points more than did the junta.

Data on the number of men in the armed forces (from IIS) also suggest that Portugal cut the size of its military as it began democracy in 1975, which coincides with SIPRI's military spending data. Spain's armed forces show a temporary increase in the 10-15 years after Franco's death, but this may be a consequence of the baby boom's reaching military service age rather than a reaction to democracy. In Chile and Greece, armed forces size fluctuates much less than does military spending as reported by SIPRI.

All of our case study countries had a military draft 1960-90, so transitions into and out of democracy are not (among these countries) associated with eliminating or introducing conscription. However, we can look at the intensity of use of the draft, such as the number of months of service required. Spain and Italy required about the same length of service throughout this period, even though months of service were declining (from 24 months to 9-10 months), and Spain was democratic only half of the time. Greece required more months service than Italy or Spain, and that service did not decline much in the 1970's or 1980's as it did in the other two countries. In that sense, the recently democratic Greece used the draft relatively intensively. Chile required 12 months service 1970-82, but since then service has been 17-24 months. The 
only South American country in our dataset to increase length of service in the 1980s was Venezuela, from 24 to 30 months, while several other South American countries were decreasing it. In short, the transition to democracy does not seem to reduce conscription intensity in our case studies, and may even increase it.

\section{Conclusions}

Over the years 1960-90, democratic countries appear similar to (economically and demographically similar) nondemocratic countries in terms of various indicators of economic and social policy - government purchases; spending on education, pensions, and welfare; corporate taxation; and capping the payroll tax. The only exception is personal income tax flatness, where we find (perhaps surprisingly) that democratic income taxes are flatter and thereby less redistributive. These results appear in both cross-country comparisons, and intertemporal comparisons for four countries whose regimes changed dramatically during the period.

Our empirical specifications are preceded by empirical studies in sociology, economics, and political science, on the impact of democracy on particular public policies. Cutright (1965), Jackman (1975), and Pampel and Williamson (1989) observed an obvious raw correlation between democracy and the introduction of pension and welfare programs (raw correlations like

these are obvious in our data too), but pointed out that economic development likely drives social programs, and is correlated with democracy. Holding constant proxies for a country's age and income, they found democracies and nondemocracies to be pretty similar in terms of their likelihood of introducing a social program. In a study of European and advanced South 
American countries about a century ago (when half of those countries were still not democratic), Lindert (1994) found, holding constant country age and income, the average democracy to be similar to the average nondemocracy in terms of spending on public pensions, welfare, unemployment, and health. A brief comment in Easterly and Rebelo's paper (1993, p. 436) indicates that they also found no relationship between democracy and a number of government tax and expenditure items, controlling for GDP per capita. To these studies we add new policy outcome measures (with an emphasis on instruments of rich-poor redistribution), potentially better measures of democracy and control variables, country case studies, and a new interpretation of the results.

It has long been recognized that dictators should be (e.g., Machiavelli 1515, Chapter XIX), and probably are, sensitive to popular support. Voting might therefore be a metaphor for public decision-making in nondemocracies. If so, the common modeling practice of keeping track of exactly who votes for what, and why, seems pretty distracting. Rather than building votes into a model, why not refer directly to efficiency considerations (for example, as in the Diamond and Mirrlees 1978 model of Social Security) or to the social compacts (as in Becker and Murphy 1988 or Kotlikoff et al 1988) for which the voting outcomes are metaphorical? More important, "voting as metaphor" is really the Chicago School approach (e.g., Peltzman 1980, p. 221) - it and our evidence are inconsistent with the three tenets of formal voting theory: that voting mutes policy preference intensity, that political power is equally distributed in democracies, and that the form of the voting game is important. The three tenets imply that democratic leaders are sensitive to popular support in significantly different ways than authoritarian leaders, as long as authoritarian leaders are sensitive to the intensity of policy 
preferences and/or can pay attention to popular support without going to the extreme of giving every citizen equal weight in public decisions.

Even if we accept that the best model of nondemocratic decisions would adhere to the three tenets, so that the same formal voting theory could be used to describe democratic and nondemocratic regimes, our empirical results would be inconsistent with this version of the voting approach because democracies and nondemocracies do have some important policy differences. The main empirical differences - both in the cross-country regressions and in the time series for countries with dramatic regime changes - are for policies relating to the process of winning and maintaining public office, rather than the social and economic policies featured in so many positive theories of the public sector. Authoritarian regimes are more likely to torture, execute, regulate religion, censor the press, and spend a lot of money on the military.

Our empirical results seem to favor the barriers-to-entry approach and, when it comes to modeling the economic and social policies, the efficiency and Chicago Political Economic schools as well. However, the reader should recognize that some previous studies looked at democracies only and found significant cross-country correlations between public spending and measures of the "type" of democratic institutions used in the country. Lindert (1994) finds that social spending was higher in democracies with higher voter turnout than in democracies with low turnout. Persson, Roland, and Tabellini (2000) find that presidential democracies spend less than parliamentary democracies. Milesi-Ferretti et al (2002) find public spending to be correlated with type of electoral system. Could it be that policy is largely independent of whether there is (fair) voting, but, when public officials are elected fairly, policy is highly dependent on the form of the voting institution? One possible answer is that spending policy depends neither on democracy nor its type, but that a within-democracy correlation between 
public spending and voting institutions appears because both simultaneously reflect efficiency considerations (as in Weingast and Marshall 1988) or interest group politics (as argued by Rokkan 1970). We leave it to future research to explore these possibilities. 
Acknowledgements

We appreciate the comments of Gary Becker, Carles Boix, Roger Myerson, Chris Rohlfs, Andrei Shleifer, Tim Taylor, Michael Waldman, and seminar participants at George Mason University and Chicago's Graduate School of Business, the research assistance of John Allread, Jakob Bluestone, Aitor Lacuesta, Martin Ljunge, Pak Shun Ng, Allison Schrager, Kevin Tsui, and the financial support of the University of Chicago's Stigler Center for the study of the Economy and the State (Mulligan), the Bank of Spain (Gil), and Spain's MEC, SEC2001-0674. 
Table 1: Democracy and Spending Policy across Countries

dependent variable: gov. consumption, 1960-90 $\quad$ education spending, $\quad$ social spending (each is a percentage of GDP) 1980-90

pension nonpen

\begin{tabular}{|c|c|c|c|c|c|c|c|}
\hline independent vars & (1) & $(2)$ & (3) & (4) & $(5)$ & $(6)$ & $(7)$ \\
\hline democracy index, 1960-90 & $\begin{array}{l}\mathbf{- 1 . 2 7} \\
(2.14)\end{array}$ & $\begin{array}{l}\mathbf{- 0 . 3 9} \\
(2.08)\end{array}$ & $\begin{array}{c}\mathbf{1 . 5 7} \\
(1.99)\end{array}$ & $\begin{array}{c}\mathbf{0 . 4 6} \\
(0.53)\end{array}$ & $\begin{array}{c}\mathbf{0 . 4 2} \\
(0.52)\end{array}$ & $\begin{array}{l}\mathbf{- 0 . 0 8} \\
(0.44)\end{array}$ & $\begin{array}{c}\mathbf{0 . 7 2} \\
(0.63)\end{array}$ \\
\hline communist dummy & $\begin{array}{l}-0.87 \\
(1.75)\end{array}$ & $\begin{array}{l}-0.10 \\
(1.77)\end{array}$ & $\begin{array}{l}-0.45 \\
(1.66)\end{array}$ & $\begin{array}{c}1.21 \\
(0.45)\end{array}$ & $\begin{array}{c}1.09 \\
(0.45)\end{array}$ & $\begin{array}{c}0.82 \\
(0.40)\end{array}$ & $\begin{array}{c}1.62 \\
(0.60)\end{array}$ \\
\hline British legal origin & $\begin{array}{c}2.80 \\
(1.28)\end{array}$ & $\begin{array}{c}3.19 \\
(1.25)\end{array}$ & $\begin{array}{c}2.91 \\
(1.17)\end{array}$ & $\begin{array}{c}0.52 \\
(0.30)\end{array}$ & $\begin{array}{c}0.53 \\
(0.31)\end{array}$ & $\begin{array}{l}-0.35 \\
(0.28)\end{array}$ & $\begin{array}{l}-0.86 \\
(0.40)\end{array}$ \\
\hline$\%$ of population aged $65+, 1960-90$ & $\begin{array}{c}0.01 \\
(0.25)\end{array}$ & $\begin{array}{c}0.08 \\
(0.25)\end{array}$ & $\begin{array}{c}0.25 \\
(0.23)\end{array}$ & $\begin{array}{c}0.04 \\
(0.06)\end{array}$ & $\begin{array}{c}0.07 \\
(0.06)\end{array}$ & $\begin{array}{c}0.58 \\
(0.05)\end{array}$ & $\begin{array}{c}0.49 \\
(0.07)\end{array}$ \\
\hline $\log ($ population $) / 10,1960-90$ & $\begin{array}{l}-9.77 \\
(2.54)\end{array}$ & $\begin{array}{l}-6.92 \\
(3.59)\end{array}$ & $\begin{array}{l}-8.16 \\
(3.36)\end{array}$ & $\begin{array}{l}-2.34 \\
(0.84)\end{array}$ & $\begin{array}{l}-2.28 \\
(0.86)\end{array}$ & $\begin{array}{l}-0.24 \\
(0.76)\end{array}$ & $\begin{array}{c}0.02 \\
(1.08)\end{array}$ \\
\hline $\begin{array}{l}\text { real GDP per capita, } 1960-89 \text { average, } \\
\log \end{array}$ & $\begin{array}{l}-2.96 \\
(0.75)\end{array}$ & $\begin{array}{l}-3.46 \\
(0.77)\end{array}$ & $\begin{array}{l}-4.58 \\
(0.76)\end{array}$ & $\begin{array}{c}0.46 \\
(0.19)\end{array}$ & $\begin{array}{l}-0.06 \\
(0.29)\end{array}$ & & \\
\hline $\begin{array}{l}\text { share of value added from agriculture, } \\
1960-90\end{array}$ & & & & & $\begin{array}{l}-3.38 \\
(1.60)\end{array}$ & $\begin{array}{l}-1.95 \\
(0.93)\end{array}$ & $\begin{array}{l}-2.01 \\
(1.35)\end{array}$ \\
\hline military spending, $\%$ of GDP & & & $\begin{array}{c}0.60 \\
(0.14)\end{array}$ & & & & \\
\hline adj-R-squared & .27 & .28 & .38 & .24 & .25 & .78 & .65 \\
\hline countries & 131 & 125 & 125 & 114 & 110 & 110 & 102 \\
\hline
\end{tabular}

Notes: (a) OLS standard errors in parenthesis. All regressions include a constant term (not shown) 
Table 2: Democracy and Tax Policy across Countries

$\begin{array}{lcccc}\text { dependent variable: } & \text { corporate tax rate 1987-90, \% } & \begin{array}{c}\text { personal income } \\ \text { tax flatness, 1973- }\end{array} & \begin{array}{c}\text { payroll tax capped, } \\ 1958-95\end{array} & \begin{array}{c}\text { total revenue as } \% \\ \text { of GDP, 1973-90 }\end{array}\end{array}$ 90

\begin{tabular}{|c|c|c|c|c|c|c|c|c|c|}
\hline independent vars & (1) & (2) & (3) & (4) & $(5)$ & (6) & (7) & (8) & (9) \\
\hline democracy index, 1960-90 & $\begin{array}{c}\mathbf{2 . 6 5} \\
(4.20)\end{array}$ & & & $\begin{array}{c}\mathbf{0 . 0 8} \\
(0.03)\end{array}$ & $\begin{array}{c}\mathbf{0 . 0 8} \\
(0.03)\end{array}$ & $\begin{array}{c}\mathbf{0 . 1 0} \\
(0.21)\end{array}$ & $\begin{array}{c}\mathbf{0 . 1 4} \\
(0.22)\end{array}$ & $\begin{array}{l}\mathbf{- 3 . 8 5} \\
(3.30)\end{array}$ & $\begin{array}{l}-6.94 \\
(3.23)\end{array}$ \\
\hline democracy index, 1975-90 & & $\begin{array}{l}\mathbf{- 0 . 3 9} \\
(4.03)\end{array}$ & $\begin{array}{l}\mathbf{- 0 . 4 3} \\
(4.12)\end{array}$ & & & & & & \\
\hline communist dummy & $\begin{array}{c}3.91 \\
(5.71)\end{array}$ & $\begin{array}{c}2.74 \\
(5.76)\end{array}$ & $\begin{array}{c}4.37 \\
(5.70)\end{array}$ & $\begin{array}{c}0.03 \\
(0.03)\end{array}$ & $\begin{array}{c}0.03 \\
(0.03)\end{array}$ & $\begin{array}{l}-0.33 \\
(0.19)\end{array}$ & $\begin{array}{l}-0.32 \\
(0.19)\end{array}$ & $\begin{array}{c}9.03 \\
(3.09)\end{array}$ & \\
\hline British legal origin & $\begin{array}{l}-1.12 \\
(2.66)\end{array}$ & $\begin{array}{c}1.79 \\
(2.58)\end{array}$ & $\begin{array}{c}4.04 \\
(2.56)\end{array}$ & $\begin{array}{c}0.02 \\
(0.02)\end{array}$ & $\begin{array}{c}0.01 \\
(0.02)\end{array}$ & $\begin{array}{l}-0.02 \\
(0.12)\end{array}$ & $\begin{array}{l}-0.10 \\
(0.13)\end{array}$ & $\begin{array}{c}1.69 \\
(1.94)\end{array}$ & $\begin{array}{c}1.81 \\
(2.00)\end{array}$ \\
\hline$\%$ of population aged $65+, 1960-90$ & $\begin{array}{c}0.32 \\
(0.47)\end{array}$ & $\begin{array}{c}0.48 \\
(0.48)\end{array}$ & $\begin{array}{c}0.79 \\
(0.47)\end{array}$ & $\begin{array}{c}0.01 \\
(0.00)\end{array}$ & $\begin{array}{l}(0.01) \\
(0.00)\end{array}$ & $\begin{array}{l}-0.85 \\
(2.41)\end{array}$ & $\begin{array}{l}-0.01 \\
(0.02)\end{array}$ & $\begin{array}{c}1.76 \\
(0.38)\end{array}$ & $\begin{array}{c}2.03 \\
(0.39)\end{array}$ \\
\hline $\log ($ population $) / 10,1960-90$ & $\begin{array}{c}4.92 \\
(7.40)\end{array}$ & $\begin{array}{c}5.22 \\
(7.42)\end{array}$ & $\begin{array}{c}4.82 \\
(6.79)\end{array}$ & $\begin{array}{l}-0.02 \\
(0.05)\end{array}$ & $\begin{array}{l}-0.02 \\
(0.05)\end{array}$ & $\begin{array}{c}0.10 \\
(0.33)\end{array}$ & $\begin{array}{c}0.26 \\
(0.33)\end{array}$ & $\begin{array}{r}-12.42 \\
(5.56)\end{array}$ & $\begin{array}{r}-12.10 \\
(5.70)\end{array}$ \\
\hline $\begin{array}{l}\text { real GDP per capita, 1960-89 } \\
\text { average, log }\end{array}$ & $\begin{array}{l}-0.51 \\
(1.80)\end{array}$ & $\begin{array}{l}-0.22 \\
(1.79)\end{array}$ & $\begin{array}{l}-1.36 \\
(2.39)\end{array}$ & $\begin{array}{c}0.02 \\
(0.02)\end{array}$ & $\begin{array}{c}0.03 \\
(0.02)\end{array}$ & $\begin{array}{c}0.09 \\
(0.09)\end{array}$ & $\begin{array}{c}0.15 \\
(0.11)\end{array}$ & $\begin{array}{c}5.21 \\
(1.24)\end{array}$ & $\begin{array}{c}5.17 \\
(1.28)\end{array}$ \\
\hline ethnolinguistic fractionalization & & & $\begin{array}{l}-0.18 \\
(4.85)\end{array}$ & & $\begin{array}{c}0.06 \\
(0.03)\end{array}$ & & $\begin{array}{c}0.36 \\
(0.23)\end{array}$ & & \\
\hline adj-R-squared & .00 & .00 & .01 & .63 & .65 & .04 & .07 & .55 & .52 \\
\hline countries & 80 & 80 & 74 & 60 & 59 & 71 & 69 & 115 & 115 \\
\hline
\end{tabular}


Table 3: Democracy across Countries - Policies that might affect Public Office Competition

\begin{tabular}{|c|c|c|c|c|c|c|}
\hline dependent variable: & $\begin{array}{l}\text { widespread } \\
\text { torture c. } 2000\end{array}$ & $\begin{array}{c}\text { fr of yrs 1976-90 } \\
\text { with death } \\
\text { penalty }\end{array}$ & $\begin{array}{l}\text { milit. } \\
\text { spend. }\end{array}$ & $\begin{array}{l}\text { civil } \\
\text { lib '73- } \\
90\end{array}$ & $\begin{array}{l}\text { rg relig } \\
\cdot 70-90\end{array}$ & $\begin{array}{c}\text { fr of years } 1985, \\
1990,1995 \\
\text { drafting }\end{array}$ \\
\hline
\end{tabular}

\begin{tabular}{|c|c|c|c|c|c|c|c|c|c|}
\hline independent vars & (1) & (2) & (3) & (4) & (5) & (6) & (7) & (8) & (9) \\
\hline $\begin{array}{l}\text { democracy index, 1960-90 } \\
\text { (but see notes) }\end{array}$ & $\begin{array}{l}\mathbf{- 0 . 2 8} \\
(0.14)\end{array}$ & $\begin{array}{l}\mathbf{- 0 . 2 9} \\
(0.13)\end{array}$ & $\begin{array}{l}\mathbf{- 0 . 5 6} \\
(0.13)\end{array}$ & $\begin{array}{l}\mathbf{- 0 . 5 9} \\
(0.13)\end{array}$ & $\begin{array}{l}\mathbf{- 3 . 4 4} \\
(1.20)\end{array}$ & $\begin{array}{c}\mathbf{0 . 5 5} \\
(0.04)\end{array}$ & $\begin{array}{l}\mathbf{- 0 . 3 0} \\
(0.15)\end{array}$ & $\begin{array}{l}\mathbf{- 0 . 0 1} \\
(0.14)\end{array}$ & $\begin{array}{c}\mathbf{0 . 1 7} \\
(0.11)\end{array}$ \\
\hline communist dummy & $\begin{array}{l}-0.17 \\
(0.12)\end{array}$ & $\begin{array}{c}0.04 \\
(0.11)\end{array}$ & $\begin{array}{c}0.11 \\
(0.10)\end{array}$ & $\begin{array}{c}0.08 \\
(0.11)\end{array}$ & $\begin{array}{c}0.87 \\
(1.03)\end{array}$ & $\begin{array}{l}-0.18 \\
(0.03)\end{array}$ & $\begin{array}{c}0.41 \\
(0.13)\end{array}$ & $\begin{array}{c}0.12 \\
(0.11)\end{array}$ & $\begin{array}{l}-0.31 \\
(0.08)\end{array}$ \\
\hline British legal origin & $\begin{array}{c}0.06 \\
(0.09)\end{array}$ & $\begin{array}{c}0.08 \\
(0.08)\end{array}$ & $\begin{array}{c}0.31 \\
(0.08)\end{array}$ & $\begin{array}{c}0.36 \\
(0.08)\end{array}$ & $\begin{array}{c}0.17 \\
(0.73)\end{array}$ & $\begin{array}{l}-0.01 \\
(0.02)\end{array}$ & $\begin{array}{l}-0.08 \\
(0.09)\end{array}$ & $\begin{array}{l}-0.44 \\
(0.08)\end{array}$ & $\begin{array}{c}0.03 \\
(0.07)\end{array}$ \\
\hline $\begin{array}{l}\text { fraction of population aged } 65+\text {, } \\
1960-90\end{array}$ & $\begin{array}{l}3.15 \\
(2.07)\end{array}$ & $\begin{array}{c}0.73 \\
(1.87)\end{array}$ & $\begin{array}{c}0.22 \\
(1.49)\end{array}$ & $\begin{array}{c}0.86 \\
(1.50)\end{array}$ & $\begin{array}{l}-21 . \\
(14 .)\end{array}$ & $\begin{array}{c}0.78 \\
(0.47)\end{array}$ & $\begin{array}{l}-0.57 \\
(1.79)\end{array}$ & $\begin{array}{c}1.57 \\
(1.56)\end{array}$ & $\begin{array}{c}4.39 \\
(1.27)\end{array}$ \\
\hline $\log ($ population $) / 10,1960-90$ & $\begin{array}{l}1.04 \\
(0.25)\end{array}$ & $\begin{array}{c}0.86 \\
(0.23)\end{array}$ & $\begin{array}{c}0.46 \\
(0.21)\end{array}$ & $\begin{array}{c}0.55 \\
(0.22)\end{array}$ & $\begin{array}{l}-1.82 \\
(2.26)\end{array}$ & $\begin{array}{l}-0.01 \\
(0.07)\end{array}$ & $\begin{array}{l}-0.07 \\
(0.25)\end{array}$ & $\begin{array}{c}0.71 \\
(0.25)\end{array}$ & $\begin{array}{c}0.01 \\
(0.19)\end{array}$ \\
\hline $\begin{array}{l}\text { real GDP per capita, 1960-89 } \\
\text { average, log }\end{array}$ & $\begin{array}{c}0.08 \\
(0.06)\end{array}$ & $\begin{array}{l}0.03 \\
(0.05)\end{array}$ & $\begin{array}{c}0.09 \\
(0.04)\end{array}$ & $\begin{array}{c}0.08 \\
(0.05)\end{array}$ & $\begin{array}{l}1.40 \\
(0.46)\end{array}$ & $\begin{array}{c}0.04 \\
(0.01)\end{array}$ & $\begin{array}{c}0.16 \\
(0.05)\end{array}$ & $\begin{array}{l}-0.06 \\
(0.06)\end{array}$ & $\begin{array}{c}0.08 \\
(0.05)\end{array}$ \\
\hline years at war since 1950 & & & & & $\begin{array}{c}0.58 \\
(0.13)\end{array}$ & & & $\begin{array}{l}-0.09 \\
(0.16)\end{array}$ & \\
\hline $\begin{array}{l}\text { armed forces per male aged } 15-24 \text {, } \\
1985-95\end{array}$ & & & & & & & & $\begin{array}{c}1.67 \\
(0.58)\end{array}$ & \\
\hline $\begin{array}{l}\text { fraction of males aged } 15-24,1985- \\
95\end{array}$ & $\begin{array}{c}2.92 \\
(2.71)\end{array}$ & $\begin{array}{c}3.93 \\
(2.45)\end{array}$ & & & & & & & \\
\hline adj-R-squared & .21 & .15 & .22 & .22 & .23 & .85 & .17 & .35 & .53 \\
\hline countries & 121 & 121 & 131 & 125 & 125 & 130 & 131 & 127 & 113 \\
\hline $\begin{array}{l}\text { Notes: (a) OLS standard errors in parenthesis } \\
\text { (b) democracy index is } 1998-99 \text { average in sp } \\
\text { (c) torture from State Department and REDR } \\
\text { (d) military spending (specification (5)) meas }\end{array}$ & $\begin{array}{l}11 \text { regress } \\
\text { ications } \\
\text { in specif } \\
\text { as perce }\end{array}$ & $\begin{array}{l}\text { include } \\
\text { and (2) } \\
\text { ions (1) } \\
\text { ge of GI }\end{array}$ & (2), res & (not sh & & & & & \\
\hline
\end{tabular}









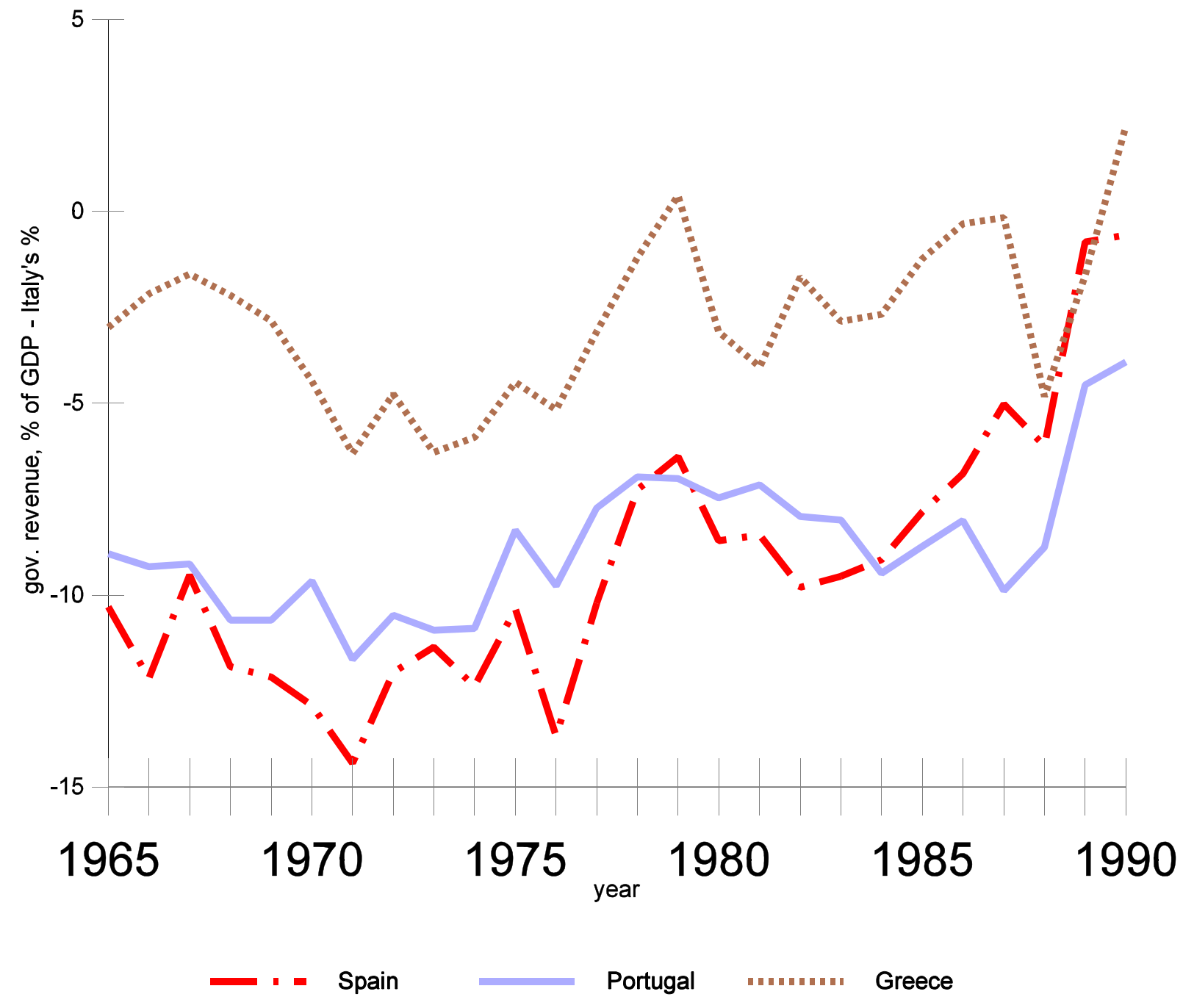

Figure 2 


\section{$\underline{\text { Data Appendix }}$}

In order of appearance in Tables 1, 2, 3, except for a few variables that share data sources.

- Democracy: Polity IV (2000). We use their indices for democracy, autocracy and executive competition. The first two are integers from 0-10 and the third integers $0-3$, but we standardize all three on a 0-1 scale and then average over the years 1960-90.

- Communist dummy: This variable takes a value of 1 if the country is considered communist by Kornai (1992) and 0 otherwise. There are 26 communist countries in our sample are North Korea, East Germany, Cuba, Yugoslavia, Nicaragua, Democratic People's Republic of Yemen, Afghanistan, Cambodia, Laos, Viet Nam, Angola, Congo, Benin, Ethiopia, Mozambique, Zimbabwe, Somalia, Albania, Bulgaria, USSR, China, Czechoslovakia, Hungary, Mongolia, Poland and Romania.

- British legal origin dummy: this variable comes from recent literature such as Djankov et al. (2002), Botero et al. (2003) and LaPorta et al. (1998). It is available for all 142 countries.

- Percent of Population over 65 years old: ILO 1996. These data are available from ILO for 137 countries, and averaged over the years 1960, 1970, 1980, 1990. For the other 5 countries (People's Democratic Republic of Yemen, Yemen Arab Republic, Djibouti, East Germany and Taiwan), we used United Nations' "Sex and age distribution of the world populations" (1984, 1996) and "Taiwan demographic factbook" (various issues). The two Yemen's did not have values for 1990, so we used 1985 instead.

- Total Population: see above

- Males aged 15-24 (total and as percent of male population): ILO 1996. ILO does not include 5 of our 142 countries: People's Democratic Republic of Yemen, Yemen Arab Republic, Djibouti, East Germany and Taiwan

- GDP per capita: Penn World Tables 1960-89. 11 countries (all nondemocratic) do not have information on PWT: Lebanon, DPR Yemen, Afghanistan, Cambodia, Viet Nam, Equatorial Guinea, Libya, Albania, Cuba, East Germany and North Korea.

- Government Consumption: same as GDP (see above). This variable is the average of the percentage of government consumption over GDP during the period 1960 to 1990, and therefore lies between 0 and 100 .

- Value Added from Agricultural Sector: This variable represents the share of value added in the economy that comes from the agricultural sector, and therefore lies between 0 and 1. World Bank collected this data and is available from their website. 15 countries in our sample have this variable missing: USA, Switzerland, Yugoslavia, Iraq, Israel, Lebanon, Qatar, Democratic People's Republic of Yemen, Arab Republic of Yemen, Afghanistan, Czechoslovakia, Cuba, North Korea, Taiwan and East Germany.

- Education Spending as a percentage of GDP: UNESCO (http://www.uis.unesco.org/pagesen/DBExpLevel.asp) in local currency times 100 divided by GDP in local currency units from Global Development Finance \& World Development Indicators, averaged over the available years 1980-90. 26 of 142 countries do not have any observations: Albania, Benin, Bhutan, Cambodia, Cuba, Czechoslovakia, Democratic People's Republic of Yemen, Gabon, West Germany, East Germany, Guinea-Bissau, Indonesia, Korea, North, Laos, Lebanon, Liberia, Libya, Papua New 
Guinea, Qatar, Somalia, Taiwan, United Arab E., USSR, Viet Nam, Yemen Arab Rep., Yugoslavia.

- Social Spending as percentage of GDP: various sources (see also Mulligan, Gil, \& Sala-i-Martin 2002). 21 of 142 countries may have public pension programs but do not have data reported by ILO and other sources: Albania, Angola, Bhutan, Botswana, Cambodia, Comoros, Democratic People's Republic of Yemen, Djibouti, Equatorial Guinea, Korea, North, Laos, Lesotho, Malawi, Mozambique, Paraguay, Qatar, USSR, Sierra Leone, Somalia, United Arab E., Yemen Arab Rep. 11 other countries are missing from specification (6) only because we do not have the agricultural variable for them. We set public pension spending to zero for 10 of the countries (Afghanistan, Congo, Gambia, Korea, Lebanon, Liberia, Nepal, Oman, Thailand, Viet Nam) for which ILO had no data and SSA indicated there was no public pension program in place throughout the period. These ten countries have missing values for nonpension social spending, since we have no information on whether and how much they spend on the nonpension social programs.

- Corporate Tax Rate: from Price Waterhouse Corporate Taxes: A Worldwide Summary, 1987 and 1990 editions. These data are not available for Switzerland, Iceland, Yugoslavia, Nicaragua, Iran, Iraq, Jordan, Lebanon, Democratic People's Republic of Yemen, Syrian Arab Republic, United Arab Emirates, Yemen Arab Republic, Afghanistan, Bangladesh, Bhutan, Myanmar, Cambodia, Sri Lanka, Laos, Nepal, Viet Nam, Djibouti, Algeria, Angola, Burundi, Central African Republic, Chad, Comoros, Congo, Benin, Equatorial Guinea, Ethiopia, Gambia, Ghana, Guinea-Bisseau, Guinea, Lesotho, Libya, Madagascar, Mali, Mauritania, Mozambique, Niger, Rwanda, Sierra Leone, Somalia, Sudan, Swaziland, Togo, Tunisia, Uganda, Burkina Faso, Albania, Bulgaria, Czechoslovakia, Mongolia, Poland, Romania, Cuba, East Germany and North Korea.

- Personal Tax Flatness: ratio of average personal income tax rate (namely, personal tax revenue/GDP from Government Finance Statistics, averaged over the years 1973-90) to the top marginal income tax rate from Price Waterhouse Individual Income Taxes: A Worldwide Summary (averaged over the years 1974, 1979, 1984, 1989; see also Becker and Mulligan, 2003).

- Caps on Payroll Tax: Mulligan and Sala-i-Martin (1999). This is an indicator variable that takes a value of 1 if the payroll tax has a cap, and 0 otherwise. We have information for 71 out of the 142 countries in the sample. The countries lacking information are Denmark, Australia, South Africa, El Salvador, Haiti, Honduras, Uruguay, Venezuela, Trinidad \& Tobago, Iraq, Jordan, Kuwait, Lebanon, Oman, Qatar, Saudi Arabia, DPR of Yemen, Yemen AR, United Arab Emirates, Bangladesh, Afghanistan, Bhutan, Myanmar, Cambodia, Laos, Pakistan, Philippines, Thailand, Viet Nam, Djibouti, Algeria, Angola, Botswana, Central African Republic, Chad, Comoros, Equatorial Guinea, Ethiopia, Guinea, Gambia, Ghana, Guinea-Bissau, Ivory Coast, Lesotho, Kenya, Libya, Madagascar, Malawi, Mali, Mauritania, Mauritius, Mozambique, Nigeria, Zimbabwe, Sierra Leone, Somalia, Sudan, Swaziland, Uganda, Fiji, Papua New Guinea, Albania, Bulgaria, USSR, China, Czechoslovakia, Mongolia, Cuba, East Germany, North Korea and Taiwan.

- Government Revenue as a percentage of GDP: International Monetary Fund's Government Finance Statistics. Averaged over the available years 1973-90. 27 of the 
142 countries have these variables missing for all of those years: Iraq, Lebanon, Qatar, Saudi Arabia, Democratic People's Republic of Yemen, Yemen Arab Republic, Afghanistan, Cambodia, Laos, Viet Nam, Algeria, Angola, Zaire, Equatorial Guinea, Libya, Mauritania, Mozambique, Rwanda, Albania, USSR, China, Czechoslovakia, Mongolia, Cuba, East Germany, North Korea and Taiwan.

- Ethnolinguistic Fractionalization: Easterly and Levine (1997). An average of various proxies for the probability that 2 people in the same country will not speak the same language (more precisely, Easterly and Levine's AVELF “average value of ETHNIC and Muller, Roberts, and Gunnemark1 and 2"). 13 of our 142 countries have missing values: Bahrain, Cuba, East Germany, Iran, Iraq, North Korea, Kuwait, Oman, Qatar, USSR, Saudi Arabia, United Arab Em., and Yemen Arab Rep.

- Torture (State Dept.): The US state department human rights reports of 1995. This dataset represents countries that the Bureau of Democracy, Human Rights, and Labor at the US Department of State submits at that calendar year to the US Congress. Since the US state department does not have a comparative report for human rights activities in the United States, information on the United States is drawn from the Amnesty International Annual Report for that calendar year. The governments of countries are coded to practice torture when there exists reports of credible evidence of torture by government agencies according to the human rights reports. An absence of credible evidence of torture, allegations of torture, or credible evidence of merely isolated incidents of torture are coded as zero, while credible evidence of widespread is coded as one. Missing for those 5 of our 142 countries not existing 1995: Czechoslovakia, East Germany, Democratic People's Republic of Yemen, Yemen Arab Rep., Yugoslavia.

- Torture (REDRESS): The governments of countries are coded to practice torture when there exists reports of systematic of widespread use of torture according to UN Human Rights Committee and the Committee against Torture, reports of the Special Rapporteur on the Question of Torture, and Amnesty International Annual Report 2002, and coded not to practice torture otherwise. Missing for those 5 of our 142 countries not existing 1995, plus Taiwan.

- Death Penalty: we took this variable from the webpage of Amnesty International (http://www.amnestyusa.org/abolish/abret2.html). They define a country as abolitionist if it has abolished death penalty from all crimes. This webpage also reports if the country has abolished death penalty in practice (have not executed anybody in a long time). These data is only available since 1976. All the countries in our sample have these data available.

- Military Spending: SIPRI. A percentage of GDP is reported for each country-year 1967-90, which we average over time for each country. 10 of our142 countries are not found in SIPRI publications: Iceland, Qatar, Afghanistan, Bhutan, Cambodia, Laos, Djibouti, Comoros, Equatorial Guinea and Mongolia. But we coded Iceland as 0 rather than missing, since the CIA World Factbook and the SIPRI www page report that Iceland has no military spending.

- Civil Liberties: Freedom House

(http://www.freedomhouse.org/research/freeworld/FHSCORES.xls). Their index takes on integer values 1-7 for each country and each year 1973-90, based on indices of human rights, personal autonomy, freedoms of expression, belief, and association (but not on the fairness of the electoral process). In order to form our index, we standardize theirs on a 
0-1 scale and average over time for each country. USSR is the only country in our sample for which this index is not available.

- Regulation of Religion: Barrett (1982, 2001). 214 countries (including each one of our 142) are coded for the years 1970,1975, 1980, 1990 according to whether there was a state religion, and what religion it was. There is also a code for "atheism," which appears almost only in Communist countries, which we interpret as a prohibition of religion. We code each country-year 1 if there was a state religion or religion prohibited, form a value for 1985 as an average of $1980 \& 1990$, and then average over time for each country.

- Conscription and Size of the Armed Forces: see Mulligan and Shliefer (2003). Each year 1985, 1990, and 1995 has a dummy variable indicating whether a country had conscripted soldiers. The dependent variable is the time average.

- Years at War Since 1950: Jones, Bremer, and Singer (1996). For each country and year, Jones, Bremer, and Singer indicate the beginning and ending date of episodes in which there was participation in a "militarized interstate dispute." For each country, we sum over time the duration of all episodes at hostility level 5 (5="war", as opposed to "Use of force," "Display of force," "Threat to use force," or "No militarized action.") and beginning 1950 or later. For example, 3 episodes of U.S. participation are coded - the Korean (duration 3.08 years), Vietnam (duration 8.93 years), and Gulf War I (duration .61 years) - so we assign the U.S. a value of 12.62. Any country not referenced during the years 1950-92 by Jones, Bremer, and Singer is presumed to have 0 years at war. 102 countries in our sample have no war years. The 40 countries with some time at war are: Argentina, Australia, Belgium, Cambodia, Canada, China, Colombia, Cuba, Cyprus, Egypt, El Salvador, Ethiopia, France, Greece, Honduras, Hungary, India, Iran, Iraq, Israel, Italy, Jordan, Korea, Korea, North, Libya, Netherlands, New Zealand, Pakistan, Philippines, Russia, Saudi Arabia, Somalia, Syrian Arab Rep., Tanzania, Thailand, Turkey, U.K., U.S.A., Uganda, and Vietnam.

- Open Trade Policy: We use the 1950-90 panel of dummy variables created by Sachs and Warner. Their sample does not contain 28 countries that we have in ours: Iceland, Panama, Bahrain, Kuwait, Lebanon, Oman, Qatar, Saudi Arabia, Democratic People's Republic of Yemen, United Arab E., Afghanistan, Bhutan, Cambodia, Laos, Viet Nam, Djibouti, Comoros, Equatorial Guinea, Lesotho, Liberia, Libya, Sudan, Swaziland, Fiji, Mongolia, Cuba, East Germany and North Korea. They automatically code Kornai's 26 communist countries as closed in all years. They code any other country-year as having "closed trade policy" if nontariff trade barriers covered more than $40 \%$ of trade, average tariff rates were $40 \%$ or more, the black market exchange rate is depreciated by $20 \%$ or more relative to the official exchange rate, there was a state monopoly on major exports. Our "trade openness" policy variable for each country is the fraction of years 1960-90 in which Sachs and Warner coded open. 
DATA APPENDIX TABLE

Variables are averaged 1960-90 unless noted otherwise

\begin{tabular}{|c|c|c|c|c|c|}
\hline Variable & Obs & Mean & Std. Dev. & Min & Max \\
\hline Democracy Polity IV & 142 & 0.312998 & 0.385798 & 0 & 1 \\
\hline Autocracy Polity IV & 142 & 0.472648 & 0.324329 & 0 & 1 \\
\hline Executive Competition & 142 & 0.517997 & 0.31414 & 0 & 1 \\
\hline British Legal Origin & 142 & 0.309859 & 0.464072 & 0 & 1 \\
\hline Population, 1000s & 142 & 28162.59 & 95652.85 & 215.75 & 910587.5 \\
\hline$\%$ Pop Aged over 65 & 142 & 5.27308 & 3.54308 & 1.64335 & 1.492585 \\
\hline $\begin{array}{l}\text { Armed Forces per Male Aged 15- } \\
24,1985-95\end{array}$ & 138 & 0.078812 & 0.079651 & 0 & 0.36459 \\
\hline $\begin{array}{l}\text { Fraction of males aged 15-24, } \\
1985-95\end{array}$ & 137 & 0.1855 & 0.0227 & 0.1077 & 0.2314 \\
\hline $\begin{array}{l}\text { Real GDP per capita, 1960-89 } \\
\text { avg }\end{array}$ & 131 & 3767.164 & 3835.325 & 287.8518 & 17772 \\
\hline $\begin{array}{l}\text { Gov Consumption, } \% \text { of GDP, } \\
1960-89 \text { avg }\end{array}$ & 131 & 18.77089 & 7.30711 & 4.59667 & 41.85556 \\
\hline Value Added from Agriculture & 127 & 0.242701 & 0.167589 & 0.00389 & 0.651298 \\
\hline $\begin{array}{l}\text { Education spending, \% of GDP, } \\
1980-90\end{array}$ & 116 & 3.796581 & 1.594092 & 1.02171 & 10.21957 \\
\hline Pension Spending, $\%$ of GDP & 121 & 1.98288 & 2.74883 & 0 & 8.83619 \\
\hline $\begin{array}{l}\text { Social Security nonpension } \\
\text { Spending, \% of GDP }\end{array}$ & 111 & 2.12448 & 2.83299 & 0 & 12.71916 \\
\hline $\begin{array}{l}\text { Price Waterhouse Corporate } \\
\text { Rate, } 1987 \& 1990\end{array}$ & 80 & 41.32047 & 10.21801 & 0 & 63.21 \\
\hline $\begin{array}{l}\text { Personal Income Tax Flatness, } \\
1973-90\end{array}$ & 60 & 0.08482 & 0.089245 & 0.000543 & 0.355169 \\
\hline
\end{tabular}


Payroll Tax Capped, 1958, 1975, 1995

Total Revenue, \% of GDP, 197390

Ethnolinguistic Fractionalization

Torture (State Dept c. 1995)

Torture (REDRESS c. 2002)

fraction of Years 1976-90 with

Death Penalty

Military Spending, \% of GDP, 1967-90

Civil Liberties Index

Fraction of years Regulating

Religion

142

133

141

Fraction of Years with Draft 198590-95

138

142

114

115

129

137

136

Years at War Since 1950

Open Trade Policy
0.58216

0.425267

0

1

25.81137

13.58387

0.9211

62.70946

0.3575306

0.3040379

0.343066

0.476475

0

1

0.220588

0.416176

0

0.412044

0

1

0.735614

4.21892

4.11964

0

23.5375

0.433538

0.311682

0

1
0.542254

0.484267

0

1

0.60628

0.473525

0

1
$1.154773 \quad 2.858361$

0.41135

0

16.24444

0.317293

0 


\section{References}

Barrett, D.B. World Christian Encyclopedia: A Comparative Survey of Churches and Religions in the Modern World. 1st ed., Oxford, Oxford University Press, 1982.

Barrett, D.B., G.T. Kurian, and T.M. Johnson. World Christian Encyclopedia: A Comparative Survey of Churches and Religions in the Modern World. 2nd ed., Oxford, Oxford University Press, 2001.

Becker, Gary S. "Competition and Democracy." Journal of Law and Economics. 1(3), 1958: $105-9$.

Becker, Gary S. and Casey B. Mulligan. "Deadweight Costs and the Size of Goverment." forthcoming, Journal of Law and Economics. 2003.

Becker, Gary S. and Kevin M. Murphy. "The Family and the State." Journal of Law and Economics. 31(1), April 1988: 1-18.

Boix, Carles. Democracy and Redistribution. Forthcoming, Cambridge University Press, 2003.

Botero, Juan, et al. “The Regulation of Labor.” manuscript, Harvard University, March 2003.

Coleman, James S. “The Possibility of a Social Welfare Function.” American Economic Review. 56(5), December 1966: 1105-22.

Crain, W. Mark. “On the Structure and Stability of Political Markets.” Journal of Political Economy. 85(4), August 1977: 829-42.

Djankov, Simeon, et al. “The Regulation of Entry.” Quarterly Journal of Economics. 117(1), February 2002: 1-37. 
Elman, Mariam Fendius. Paths to Peace: Is Democracy the Answer? Cambridge, MA: MIT Press, 1997.

Friedman, Milton. Capitalism and Freedom. Chicago: University of Chicago Press, 1962.

Gill, Anthony. Political Origins of Religious Liberty. manuscript, University of Washington, 2002.

Glaeser, Edward L. and Andrei Shleifer. "Legal Origins." Quarterly Journal of Economics. 117(4), November 2002: 1193-1229.

Grossman, Gene M. and Elhanan Helpman. "Electoral Competition and Special Interest Politics." Review of Economic Studies. 63(2), April 1996: 265-86.

Habibi, Nader. "Budgetary Policy and Political Liberty: A Cross-Sectional Analysis." World Development. 22(4), April 1994: 579-86.

International Institute for Strategic Studies. The Military Balance. London: Institute for Strategic Studies, various issues.

Jones, Daniel M., Stuart A. Bremer, and J. David Singer. "Militarized Interstate Disputes, 18161992: Rationale, Coding Rules, and Empirical Patterns." Conflict Management and Peace Science. 15(2), 1996: 163-213.

La Porta, Rafael, Florencio Lopez de Silanes, and Andrei Shleifer. "Law and Finance." Journal of Political Economy. 106(6), December 1998: 1113-55.

Ledyard, John O. "The Pure Theory of Large Two-Candidate Elections." Public Choice. 44(1), 1984: 7-41.

Lindert, Peter. "The Rise of Social Spending, 1880-1930." Explorations in Economic History. 31(1), January 1994: 1-37. 
Lott, John R., Jr. "Brand Names and Barriers to Entry in Political Markets.” Public Choice. 51(1), 1986: 87-92.

Kornai, János. The Socialist System: The Political Economy of Communism. Princeton, NJ: Princeton University Press, 1992.

Kotlikoff, Laurence J., Torsten Persson, and Lars Svensson. "Social Contracts and Assets: A Possible Solution to the Time Inconsistency Problem." American Economic Review. 78(4), September 1988: 662-77.

Machiavelli, Niccolo. The Prince. Thomas G. Bergin, trans. Northbrook, IL: AHM Publishing Company, 1947 (1515).

Meltzer, Allan H. and Scott F. Richard. “A Rational Theory of the Size of Government.” Journal of Political Economy. 89(5), October 1981: 914-27.

Mulligan, Casey B., Ricard Gil, and Xavier Sala-i-Martin. "Social Security and Democracy." NBER Working paper no. 8958, May 2002.

Mulligan, Casey B. and Andrei Shleifer. "Population and Regulation.” manuscript, Harvard University, November 2002.

Mulligan, Casey B. and Andrei Shleifer. "Conscription.” manuscript, Harvard University, May 2003.

Myerson, Roger B. “Analysis of Democratic Institutions: Structure, Conduct and Performance." Journal of Economic Perspectives. 9(1), Winter 1995: 77-89.

Niskanen, William A. “Autocratic, Democratic, and Optimal Government.” Economic Inquiry. 35(3), July 1997: 464-79.

Olson, Mancur. "Dictatorship, Democracy, and Development." American Political Science Review. 87(3), September 1993: 567-76. 
Olson, Mancur and Martin McGuire. "The Economics of Autocracy and Majority Rule: The Invisible Hand and the Use of Force." Journal of Economic Literature. 34(1), March 1996: 72-97.

Peltzman, Sam. "The Growth of Government." Journal of Law and Economics. 23(2), Oct. 1980: 209-87.

Polity IV Project. Political Regime Characteristics and Transition, 1800-2000. Electronic data file (version p4v2000). College Park, MD: CIDCM, University of Maryland, 2000.

Pryor, FL. Public Expenditures in Communist and Capitalist Nations. London: George Allen and Uwin, 1968.

Rokkan, Stein. Citizens, Elections, Parties: Approaches to the Comparative Study of the Process of Development. New York: McKay, 1970.

Ross, Thomas W. "Raising an Army: A Positive Theory of Military Recruitment." Journal of Law and Economics. 37(1), April 1994: 109-31.

Sachs, Jeffrey D., and Andrew Warner. "Economic Reform and the Process of Global Integration.” Brookings Papers on Economic Activity. 1, 1995: 1-95.

Schmitter, Phillipe C. "Military Intervention, Political Competitiveness, and Public Policy in Latin America, 1950-67." in Morris Janowitz and Jacques van Doom, eds. On Military Ideology. Rotterdam: Rotterdam University Press, 1971.

Tsui, Kevin Ka Kin. "Party Competition, Influence Buying, and Public Policy Design." manuscript, University of Chicago, December 2002.

Stigler, George J. "Director's Law of Public Income Redistribution." Journal of Law and Economics. 13(1), April 1970: 1-10. 
Tullock, Gordon. "Problems of Majority Voting." Journal of Political Economy. 67(6), December 1959: 571-9.

Tullock, Gordon. "Entry Barriers in Politics.” American Economic Review. 55(1), March 1965: 458-66.

Tullock, Gordon. Autocracy. Boston, MA: Kluwer Academic Publishers, 1987.

Tullock, Gordon. “Undemocratic Governments.” Kyklos. 55(2), 2002: 247-64.

Volckart, Oliver. "State Building by Bargaining for Monopoly Rents.” Kyklos. 53(3), 2000: 265 91.

Weingast, Barry R. and William J. Marshall. "The Industrial Organization of Congress." Journal of Political Economy. 96(1), February 1988: 132-63.

Wintrobe, Ronald. "The Tinpot and the Totalitarian: An Economic Theory of Dictatorship." American Political Science Review. 84(3), September 1990: 849-72. 